\title{
Iron status, energy intake, and nutritional status of healthy young Asian children
}

\author{
M B Duggan, G Steel, G Elwys, L Harbottle, C Noble
}

\begin{abstract}
The iron status, dietary intake, and protein energy nutritional status of healthy Asian children ranging in age from 4 to $\mathbf{4 0}$ months was investigated. The serum ferritin, erythrocyte zinc protoporphyrin, haemoglobin and mean corpuscular haemoglobin concentrations, and mean corpuscular volume were determined in a community study of $\mathbf{1 3 8}$ children. Protein energy nutritional status was estimated by anthropometry and a four or five day weighed dietary inventory was completed by 97 children. Concentrations of the serum ferritin, haemoglobin, and mean corpuscular haemoglobin, and the mean corpuscular volume decreased progressively with increasing age. The mean values for these four indices were significantly lower in toddlers between 21 and 23 months age than in infants $<6$ months old. The mean erythrocyte zinc protoporphyrin was high in the first six months, later falling and rising again to peak in the $\mathbf{2 1}$ to $\mathbf{2 3}$ month age group. Thirty five per cent of children were iron deficient (serum ferritin concentration $<10 \mu \mathrm{g} / \mathrm{l}$ ) and low values for the mean corpuscular volume and mean corpuscular haemoglobin were observed in $33 \%$ and $35 \%$ respectively and $17 \%$ were anaemic (haemoglobin concentration $<110$ g/l). No association was observed between biochemical iron status and the dietary intake of energy or iron. Nor was there an association between protein energy nutritional status and iron status. Screening for iron deficiency in communities at risk is recommended and nutrition education using trained link workers is preferred to prophylactic iron treatment.
\end{abstract}

Department of
Paediatrics,
University of Sheffield,
Clinical Sciences Centre,
Northern General
Hospital,
Herries Road,
Sheffield S5 7AU
M B Duggan
L Harbottle
C Noble
Haematology
Department,
Sheffield Children's
Hospital
G Steel
Haematology
Department,
Northern General
Hospital
G Elwys
Correspondence to:
Dr Duggan.
Accepted 29 July 1991

In addition to its vital role as an oxygen carrier in haemoglobin and myoglobin, iron is an important cofactor in the synthesis of DNA and neurotransmitters and in mitochondrial cytochromes in many organs. Work capacity and intellectual performance in adults ${ }^{1}$ and neurological development in young children ${ }^{2}$ are adversely affected by iron deficiency. Effective treatment of iron deficiency in young children is followed by a spurt in growth and neurological development.

Iron deficiency is common in children of Asian parentage. ${ }^{56}$ The iron status of 138 apparently healthy Asian babies born in Sheffield was investigated during a comprehensive community nutrition study.

Subjects and methods

The overall objective was to study the relation- ship between diet and the nutritional and iron $\frac{\bar{F}}{\bar{G}}$ status of Asian children during weaning. Healthy children between 4 and 24 months of $\Omega$ age were recruited over a 12 month period from is the registers of the nine child health and general $\vec{\circ}$ practitioner clinics which serve the majority of the Asian community. The upper age limit was $\vec{\omega}$ later extended to $\mathbf{4 0}$ months in order to map the upper limit of iron deficiency. The protocol was explained in the appropriate vernacular at a $\&$ home visit and informed parental consent was obtained in all cases. Recruitment and dietary and anthropometric observations were carried out under supervision (MBD and LH) by three specifically trained Asian link workers. One hundred and thirty eight parents agreed to a venous blood sample being taken from their $\mathbb{D}$ child (MBD), and 97 of these children completed a weighed dietary inventory.

Haematological investigations included measurement of serum ferritin concentration (by $\bar{\theta}$ immunoradiometry), erythrocyte zinc protoporphyrin (by the Protofluor Z System, Helena Laboratories) haemoglobin, red cell indices, total and differential white blood count. Iron deficiency was defined by a serum ferritin concentration $<10 \mu \mathrm{g} / \mathrm{l}$ or a erythrocyte zinc protoporphyrin $>80 \mu \mathrm{mol} / \mathrm{mol}$ haem. Values for the erythrocyte zinc protoporphyrin $>200$ $\mu \mathrm{mol} / \mathrm{mol}$ haem (the upper limit for technical accuracy of the apparatus) were represented by 200 in statistical analysis. Haemoglobin electrophoresis was carried out when indicated by anaemia (haemoglobin $<110 \mathrm{~g} / \mathrm{l}$ ) or abnormal red cell indices. Differences between the numbers of observations of serum ferritin $(n=128)$ and erythrocyte zinc protoporphyrin and red cell indices ( $n=135$ each) are due to problems with volume and clotting respectively. Children were weighed naked and crown-heel length was measured (using the Weylux on Supreme beam balance and Holtain infant measuring table). Protein energy nutritional status was estimated by anthropometry, malnutrition being defined as a negative deviation in weight for body length of at least 2 SDs from the reference mean (data of the World Health Organisation (WHO) 1983). ${ }^{7}$ A weighed dietary inventory was collected for four days (five days for children $>12$ months) using the PETRA electronic recording balance (Cherlyn Electronics Ltd) which obviated the need for (parental) written records. The taped nutritional information was translated from the vernacular, coded for food composition, and analysed using the Microdiet programme (Salford University) with an extended data base. The dietetic methodology will be described elsewhere in 
detail (M B Duggan and L Harbottle, unpublished data). Parents and general practitioners were made aware of all iron deficient children, and in most cases treatment was instituted. The study protocol was accepted by the Northern General Hospital medical ethics committee.

\section{Results}

The haematological results, grouped by age with sexes combined, are illustrated in table 1 . The mean concentrations of the serum ferritin, haemoglobin, and mean cell haemoglobin, and mean cell volume (table 1) fell progressively with age to reach a nadir in the 21 to $<24$ months age group. The mean concentration of the erythrocyte zinc protoporphyrin, which was marginally higher in infants $<6$ months, rose to peak in the second year of life. The prevalence of iron deficiency estimated by the different indices is illustrated in table 2. Haemoglobinopathy was diagnosed in three children: one with $\beta$ thalassaemia trait, one haemoglobin $\mathrm{E}$ trait, and one with combined traits for $\beta$ thalassaemia and haemoglobin E. All anaemic children were iron deficient.

The daily food intakes of energy and iron were analysed according to biochemical iron status in the 97 children with available dietary data (table 3). The mean standardised energy intake and the mean iron intake was, at all ages, similar in children with low and normal serum ferritin concentrations; analyses were by Student's $t$ test. The mean iron intake in both groups and at almost all ages, failed to supply the recommended daily amount for iron (5.0 mg/day, Department of Health and Social Security, 1974). The protein energy nutritional status (estimated by the weight for length SD score) is illustrated in table 3 . No significant association between protein energy nutritional status and biochemical iron status was observed. The mean (SE) weight for length SD score in $\mathbf{4 5}$ children with low and 83 with normal serum ferritin concentrations is given by -0.559

Table 1 Haematological data on 138 healthy Asian children aged from 4 to 40 months

\begin{tabular}{|c|c|c|c|c|c|}
\hline $\begin{array}{l}\text { Age group } \\
\text { (months) }\end{array}$ & $\begin{array}{l}\text { Ferritin } \\
(\mu \mathrm{g} / l)\end{array}$ & $\begin{array}{l}\text { Erythrocyte zinc } \\
\text { protoporphyrin } \\
\text { (umol/mol haem) }\end{array}$ & $\begin{array}{l}\text { Haemoglobin } \\
(\mathrm{g} / \mathrm{l})\end{array}$ & $\begin{array}{l}\text { Mean corpuscular } \\
\text { volume } \\
(f l)\end{array}$ & $\begin{array}{l}\text { Mean corpuscular } \\
\text { haemoglobin } \\
(p g)\end{array}$ \\
\hline $\begin{array}{l}3-<6 \\
\text { Mean } \\
\text { SE } \\
\text { No } \\
6-<9\end{array}$ & $\begin{array}{l}69 \cdot 5 \\
24 \cdot 02 \\
8\end{array}$ & $\begin{array}{l}91 \\
15 \cdot 42 \\
8\end{array}$ & $\begin{array}{c}118 \cdot 8 \\
3 \cdot 26 \\
8\end{array}$ & $\begin{array}{c}77 \cdot 3 \\
2 \cdot 12 \\
8\end{array}$ & $\begin{array}{l}25 \cdot 7 \\
0 \cdot 64 \\
8\end{array}$ \\
\hline $\begin{array}{l}\text { Mean } \\
\text { SE } \\
\text { No } \\
9-<12\end{array}$ & $\begin{array}{l}37 \cdot 27 \\
7 \cdot 155 \\
15\end{array}$ & $\begin{array}{l}77 \cdot 94 \\
7 \cdot 55 \\
18\end{array}$ & $\begin{array}{c}114 \cdot 9 \\
2 \cdot 12 \\
17\end{array}$ & $\begin{array}{l}72 \cdot 9 \\
2 \cdot 03 \\
17\end{array}$ & $\begin{array}{l}24 \cdot 1 \\
0 \cdot 69 \\
17\end{array}$ \\
\hline $\begin{array}{l}\text { Mean } \\
\text { SE } \\
\text { No } \\
12-<15\end{array}$ & $\begin{array}{l}24 \cdot 06 \\
3.53 \\
16\end{array}$ & $\begin{array}{l}74 \cdot 3 \\
4 \cdot 885 \\
20\end{array}$ & $\begin{array}{c}114 \cdot 8 \\
1.6 \\
20\end{array}$ & $\begin{array}{l}72 \cdot 9 \\
1 \cdot 28 \\
20\end{array}$ & $\begin{array}{l}23 \cdot 7 \\
0 \cdot 34 \\
20\end{array}$ \\
\hline $\begin{array}{l}\text { Mean } \\
\text { SE } \\
\text { No } \\
15-<18\end{array}$ & $\begin{array}{l}17 \cdot 07 \\
3 \cdot 43 \\
15\end{array}$ & $\begin{array}{l}89 \cdot 69 \\
12 \cdot 32 \\
13\end{array}$ & $\begin{array}{c}110 \cdot 9 \\
2 \cdot 63 \\
14\end{array}$ & $\begin{array}{l}70 \cdot 6 \\
2 \cdot 26 \\
14\end{array}$ & $\begin{array}{l}22 \cdot 9 \\
0 \cdot 75 \\
14\end{array}$ \\
\hline $\begin{array}{c}\text { Mean } \\
\text { SE } \\
\text { No } \\
18-<21\end{array}$ & $\begin{array}{l}13 \cdot 88 \\
3.033 \\
17\end{array}$ & $\begin{array}{l}92 \cdot 55 \\
12 \cdot 1 \\
17\end{array}$ & $\begin{array}{c}112 \cdot 6 \\
3 \cdot 58 \\
17\end{array}$ & $\begin{array}{l}70 \cdot 5 \\
2 \cdot 31 \\
16\end{array}$ & $\begin{array}{l}22 \cdot 3 \\
0 \cdot 71 \\
16\end{array}$ \\
\hline $\begin{array}{l}\text { Mean } \\
\text { SE } \\
\text { No } \\
21-<24\end{array}$ & $\begin{array}{l}19 \cdot 93 \\
5 \cdot 447 \\
14\end{array}$ & $\begin{array}{l}90 \cdot 87 \\
12 \cdot 76 \\
15\end{array}$ & $\begin{array}{c}109 \cdot 9 \\
2 \cdot 8 \\
15\end{array}$ & $\begin{array}{l}69 \cdot 7 \\
1 \cdot 78 \\
15\end{array}$ & $\begin{array}{l}22 \cdot 3 \\
0 \cdot 68 \\
15\end{array}$ \\
\hline $\begin{array}{c}\text { Mean } \\
\text { SE } \\
\text { No } \\
24-<30\end{array}$ & $\begin{array}{l}10 \cdot 57^{*} \\
2 \cdot 431 \\
14\end{array}$ & $\begin{array}{l}104 \cdot 8 \\
16 \cdot 09 \\
13\end{array}$ & $\begin{array}{c}106 \cdot 8^{*} \\
4 \cdot 25 \\
13\end{array}$ & $\begin{array}{l}67 \cdot 7^{*} \\
3 \cdot 3 \\
13\end{array}$ & $\begin{array}{l}21 \cdot 9^{*} \\
1 \cdot 26 \\
13\end{array}$ \\
\hline $\begin{array}{l}\text { Mean } \\
\text { SE } \\
\text { No } \\
\geqslant 30\end{array}$ & $\begin{array}{l}16 \cdot 82 \\
2 \cdot 933 \\
17\end{array}$ & $\begin{array}{l}70 \cdot 68 \\
9 \cdot 569 \\
18\end{array}$ & $\begin{array}{c}115 \cdot 2 \\
2 \cdot 71 \\
18\end{array}$ & $\begin{array}{l}72 \cdot 1 \\
1 \cdot 75 \\
18\end{array}$ & $\begin{array}{l}23 \cdot 9 \\
0 \cdot 77 \\
18\end{array}$ \\
\hline $\begin{array}{l}\text { Mean } \\
\text { SE } \\
\text { No }\end{array}$ & $\begin{array}{l}16 \\
4 \cdot 414 \\
12\end{array}$ & $\begin{array}{l}89 \cdot 08 \\
15 \cdot 97 \\
13\end{array}$ & $\begin{array}{c}108 \cdot 8 \\
3 \cdot 64 \\
13\end{array}$ & $\begin{array}{c}68 \cdot 5 \\
3 \cdot 46 \\
13\end{array}$ & $\begin{array}{l}22 \cdot 2 \\
1.33 \\
13\end{array}$ \\
\hline
\end{tabular}

*Mean value for serum ferritin, haemoglobin, mean corpuscular volume, and mean corpuscular haemoglobin was significantly $(p<0.05)$ lower at $21-<24$ months than at $3-<6$ months.

Table 2 Percentage of observations indicating iron deficiency (anaemia) in 138 healthy Asian children (the selected cut off point is in parentheses under indicator of anaemia)

\begin{tabular}{|c|c|c|c|c|c|c|c|}
\hline $\begin{array}{l}\text { Age group } \\
\text { (months) }\end{array}$ & $\begin{array}{l}\text { Total } \\
\text { No }\end{array}$ & $\begin{array}{l}\% \text { Ferritin } \\
\text { deficient } \\
(<10 \mu g / l)\end{array}$ & $\begin{array}{l}\text { Total } \\
\text { No }\end{array}$ & $\begin{array}{l}\% \text { Erythrocyte } \\
\text { zinc } \\
\text { protoporphyrin } \\
\text { deficient } \\
(>80 \mu \mathrm{mol} / \mathrm{mol} \\
\text { haem })\end{array}$ & $\begin{array}{l}\% \text { Anaemic } \\
(\text { haemoglobin } \\
<110 \mathrm{~g} / l)^{*}\end{array}$ & $\begin{array}{l}\% \text { Low } \\
\text { mean corpusuclar } \\
\text { volume } \\
(<70 \mathrm{fl})^{*}\end{array}$ & $\begin{array}{l}\% \text { Low } \\
\text { mean corpuscular } \\
\text { haemoglobin } \\
(<23 \mathrm{pg})^{*}\end{array}$ \\
\hline $\begin{array}{l}<12 \\
12-<24 \\
\geqslant 24\end{array}$ & $\begin{array}{l}39 \\
60 \\
29\end{array}$ & $\begin{array}{l}10 \\
48 \\
34\end{array}$ & $\begin{array}{l}46 \\
58 \\
31\end{array}$ & $\begin{array}{l}35 \\
50 \\
32\end{array}$ & $\begin{array}{l}99 \\
24 \\
14\end{array}$ & $\begin{array}{l}18 \\
42 \\
35\end{array}$ & $\begin{array}{l}20 \\
46 \\
35\end{array}$ \\
\hline Total & $128 \dagger$ & 34 & $135 t$ & 41 & 17 & 33 & 35 \\
\hline
\end{tabular}

*Total numbers in each group the same as for erythrocyte protoporphyrin.

tDiscordance in numbers caused by insufficient volume or clotting of sample. 
Table 3 Comparison of dietary energy and iron intakes and of protein energy nutritional status (weight for length SD score) according to biochemical iron status in 97 healthy Asian children, 33 with low and 64 with normal serum ferritin concentration

\begin{tabular}{|c|c|c|c|c|c|c|}
\hline \multirow[t]{2}{*}{$\begin{array}{l}\text { Age group } \\
\text { (months) }\end{array}$} & \multicolumn{3}{|c|}{$\begin{array}{l}\text { Iron deficient } \\
(\text { serum ferritin }<10 \mu \mathrm{g} / \mathrm{l})\end{array}$} & \multicolumn{3}{|c|}{$\begin{array}{l}\text { Iron adequate } \\
(\text { serum ferritin } \geqslant 10 \mu g / l)\end{array}$} \\
\hline & $\begin{array}{l}\text { Energy intake } \\
(\mathrm{kJ} / \mathrm{kg} / \text { day })\end{array}$ & $\begin{array}{l}\text { Iron intake } \\
\text { (mg/day) }\end{array}$ & $\begin{array}{l}\text { Weight for length } \\
S D \text { score }\end{array}$ & $\begin{array}{l}\text { Energy intake } \\
(\mathrm{kf} / \mathrm{kg} / \text { day })\end{array}$ & $\begin{array}{l}\text { Iron intake } \\
(m g / d a y)\end{array}$ & $\begin{array}{l}\text { Weight for length } \\
S D \text { score }\end{array}$ \\
\hline $\begin{array}{l}<6 \\
\quad \text { Mean } \\
\text { SE } \\
\text { No } \\
6-<12\end{array}$ & No values & No values & No values & $\begin{array}{r}349 \\
37 \\
13\end{array}$ & $\begin{array}{r}5 \cdot 72 \\
0 \cdot 48 \\
13\end{array}$ & $\begin{array}{c}-0.28 \\
0 \cdot 285 \\
13\end{array}$ \\
\hline $\begin{array}{c}\text { Mean } \\
\text { SE } \\
\text { No } \\
12-<18\end{array}$ & $\begin{array}{r}345 \\
32 \\
6\end{array}$ & $\begin{array}{r}3.17 \\
0.39 \\
6\end{array}$ & $\begin{array}{c}0.11 \\
0.462 \\
6\end{array}$ & $\begin{array}{r}316 \\
23 \\
19\end{array}$ & $\begin{array}{r}4 \cdot 15 \\
0.54 \\
19\end{array}$ & $\begin{array}{c}-0.27 \\
0.232 \\
19\end{array}$ \\
\hline $\begin{array}{l}\text { Mean } \\
\text { SE } \\
\text { No } \\
18-<24\end{array}$ & $\begin{array}{r}353 \\
39 \\
14\end{array}$ & $\begin{array}{r}4.91 \\
0.91 \\
14\end{array}$ & $\begin{array}{c}-0.42 \\
0.266 \\
14\end{array}$ & $\begin{array}{r}354 \\
32 \\
13\end{array}$ & $\begin{array}{r}3 \cdot 72 \\
2 \cdot 10 \\
13\end{array}$ & $\begin{array}{c}-1 \cdot 0 \\
0 \cdot 192 \\
13\end{array}$ \\
\hline $\begin{array}{l}\text { Mean } \\
\text { SE } \\
\text { No } \\
\geqslant 24\end{array}$ & $\begin{array}{r}264 \\
30 \\
7\end{array}$ & $\begin{array}{r}2.56 \\
0.41 \\
7\end{array}$ & $\begin{array}{c}-1 \cdot 28 \\
0 \cdot 299 \\
7\end{array}$ & $\begin{array}{r}337 \\
32 \\
9\end{array}$ & $\begin{array}{r}4.81 \\
1.17 \\
9\end{array}$ & $\begin{array}{c}-0.21 \\
0.417 \\
9\end{array}$ \\
\hline $\begin{array}{l}\text { Mean } \\
\text { SE } \\
\text { No }\end{array}$ & $\begin{array}{r}302 \\
31 \\
6\end{array}$ & $\begin{array}{r}3.81 \\
0.75 \\
6\end{array}$ & $\begin{array}{r}0.56 \\
0.62 \\
6\end{array}$ & $\begin{array}{r}322 \\
38 \\
10\end{array}$ & $\begin{array}{r}3.34 \\
0.55 \\
10\end{array}$ & $\begin{array}{c}-0.9 \\
0.292 \\
10\end{array}$ \\
\hline
\end{tabular}

$(0 \cdot 1149)$ and $-0.3844(0 \cdot 1417)$ respectively (analysed by Student's $t$ test; this was not significant).

\section{Discussion}

How well do our data represent the situation in Sheffield? We located the parents of 310 of the estimated 600 eligible chidren aged 4 to 24 months and registered in the selected geographical area. Agreement to take part and completion of the dietary study appeared to reflect maternal confidence and control of decision making and the vulnerable may have been under represented. The 29 children $>24$ months may be less representative of their age group.

Our observation of a high prevalence of iron deficiency in Asian toddlers agrees with reports from other British cities. ${ }^{589}$ Our results delineate the gradual deterioration with increasing age of a number of haematological indicators of iron status. We attempted to identify risk factors for iron deficiency and failed to demonstrate any association between present iron deficiency and previous low birth weight, initial feeding method, or age at commencement of weaning. Birthweight data were available on 113 children (mean $3100 \mathrm{~g}$ ). Fourteen (17\%) had been of low birth weight, and four $(28 \%)$ of these were iron deficient compared with $32 \%$ of children born at a normal birth weight (not significant by $\left.\chi^{2}\right)$. Twenty four $(17 \%)$ of the 140 children with information on initial feeding method had been exclusively breast fed for four months and $80 \%$ had started solids by 6 months of age. Inspection of the data suggested no effect on iron status attributable to differences in infant feeding method, or to the age of starting weaning. Intestinal blood loss due to parasites was not investigated. It is manifestly not a problem in this city and can probably be discounted.

Our data suggest that iron status is lowest more than a year after the commencement of weaning. How satisfactory was the weaning diet? Although the mean energy intake at all ages, and irrespective of iron status, was lower than the WHO (1985) recommendations, ${ }^{9}$ it was reasonably close to recorded intakes by healthy English children. ${ }^{10}$ The fat and protein

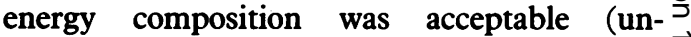
published data, M B Duggan and L Harbottle). $\vec{\nabla}$ Their satisfactory protein energy nutritional $\mathbb{\Omega}^{\circ}$ status (table 3 ) is supportive evidence for the adequacy of the children's dietary intake. The similar levels of energy intake in iron deficient and iron adequate children suggest that iron $\vec{\ominus}$ deficiency had no significant effect on appetite (intake). Warrington and Storey compared a group of healthy Asian children with white controls matched for age and socioeconomic status. ${ }^{10} 11$ They observed a higher prevalence of iron deficiency in Asian children despite $\stackrel{\mathbb{Q}}{\mathscr{}}$ similar rates of both growth and similar dietary $\overrightarrow{\vec{F}}$ intakes of energy and iron. In this study the mean dietary iron intake in all children failed, at most ages, to meet the recommended daily? amount for iron.

The surprising observation of a similarly low level of iron intake in biochemically iron deficient and non-deficient children needs to be considered in context. Firstly, the estimate of iron intake given by food composition tables is approximate, and it does not distinguish between haem and non-heam iron. $\frac{T}{2}$ Furthermore iron intake is expressed in $\mathrm{mg} /$ day without reference to body weight or $\mathcal{N}$ energy intake, although no difference between $N$ the two groups emerged from analysis of data N expressed in $\mathrm{mg}$ iron $/ 418 \mathrm{~kJ}(100 \mathrm{kcal})$. In the absence of an ideal biomarker for iron deficiency, serum ferritin concentration was selected as an indicator. The serum ferritin has a skewed distribution, and although the 0 concentration falls at an early stage of defi-

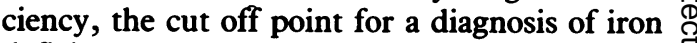
deficiency is somewhat arbitrary. A low $\mathbb{D}$ concentration may rise during infection giving a false negative result. Any of these factors may have blurred distinctions between truly deficient and normal children. Nevertheless, the significant linear correlation between serum ferritin $(y)$ and iron intake $(x)(r=0.22$; $t=2 \cdot 20$ with $95 \mathrm{df}$ ) suggests that iron status is 
influenced by iron intake. Erythrocyte zinc protoporphyrin is also an imperfect indicator. The concentration of erythrocyte zinc protoporphyrin is physiologically high soon after birth and discordance between the erythrocyte zinc protoporphyrin and the other indicators in children $<12$ months is evident in table 2 .

Subtle dietary differences over long periods of time, and imperfectly estimated in a cross sectional study, cannot be appreciated or quantified in a few days' observations. A longitudinal study would permit analysis of the long term effects of differences in the progress and practice of weaning. It might also help to explain the observation of adequate iron status in children who may have had low iron intakes since birth. The possible effects of vitamin $C$ on the bioavailability of non-haem iron, or of riboflavin on iron turnover were considered. Inspection of data failed to demonstrate a link between intake of vitamin $\mathrm{C}$ or riboflavin and the concentration of serum ferritin. Nor was the trend towards a higher prevalence of iron deficiency in fresh milk fed children significant. ${ }^{10}$ Reliance on sweet foods by parents attempting to maintain a Halal* diet and to follow the local weaning mores is well recognised. ${ }^{12-14}$ Ignoring the considerable contribution of cows' milk to commercial baby foods, fresh or formula milk was the major energy source (providing more than $60 \%$ of dietary energy) until the age of 18 months. Milk is a poor source of iron and the bioavailability of iron in both formula and cows' milk is uncertain.

In socioeconomically deprived areas with a high proportion of Asian children, late weaning on to iron poor diets may result in a greater problem than is apparent in Sheffield. ${ }^{12} 13$ These and previous findings suggest that more than a third of British Asian babies may be iron deficient. $^{5-7}$ In the absence of a link between protein energy nutrition and biochemical iron status, they may not be identified as at risk. We strongly support the case for screening for iron deficiency in vulnerable groups, which was cautiously proposed by the joint working party on child health surveillance. ${ }^{14}$ We would favour the use of a more sensitive indicator than the haemoglobin concentration ( M B Duggan, et $a l$, unpublished observations).

Prevention of iron deficiency is the next consideration. In view of the fact that iron supplementation of formula did not protect against iron deficiency, should we recommend iron prophylaxis as for other 'at risk' babies such as the previously low birth weight? If so,

*Most Sheffield Asians follow the Koranic injunction to avoid pork and to eat only Halal meat which has been ritually slaughtered and dedicated to Allah. when should they be treated? Our link workers reported complaints and confusion over iron dosages dispensed for our iron deficient children. We predict that general prophylaxis would prove neither feasible nor acceptable. The link with socioeconomic deprivation reported from rich $^{15}$ and poor countries ${ }^{1}$ suggests that preventive nutrition education may be a preferable option. Appropriately trained and supported link workers would give practical nutrition teaching based on weaning recipes developed by (Asian) nutritionists, to all Asian mothers attending child health clinics. ${ }^{16}$

Although poverty, linguistic isolation, and difficulties in adaptation of Halal diets for weanlings have combined to make this a particularly vulnerable group, iron deficiency is not confined to Asian children. ${ }^{58}$ If the reported association between relatively mild, that is, nonanaemic iron deficiency and delay in neurological development is confirmed, the present findings will have broader implications for child health.

Acknowledgements to the Health Promotion Research Trus which supported LH, CN, and the three link workers Miss P Akhtar, Mrs S Jan Khan, and Mrs J Ahmed to whom we are also grateful.

1 Hercberg S, Galan P, Dupin H. Iron deficiency in Africa. In: Bourne $\mathbf{G H}$, ed World review of nutrition and dietetics. Basel: Karger, 1987:202-36.

2 Walter T, Kovalskys J, Stekel A. Effect of mild iron deficiency on infant mental development scores. $\mathcal{F}$ Pediatr 1983;102: 519-22.

3 Walter T, de Andraca I, Chadud P, Perales CG. Iron deficiency anaemia adverse effects on infant psychomotor development. Pediatrics 1989;84:7-17.

4 Aukett MA, Parks YA, Scott PH, Wharton BA. Treatment with iron increases weight gain and psychomotor development. Arch Dis Child 1986;61:849-57.

5 Erhardt $P$. Iron deficiency in young Bradford children from different ethnic groups. $B M \mathcal{F} 1986 ; 292: 90-3$.

6 Grindulis H, Scott PH, Belton NR, Wharton BA. Combined deficiency of iron and vitamin $\mathrm{D}$ in Asian toddlers. Arch Dis Child 1986;61:843-8.

7 World Health Organisation. Measuring change in nutritional status. Geneva: WHO, 1983.

8 Mills AF. Surveillance for anaemia; risk factors in patterns of milk intake. Arch Dis Child 1990;65:428-31.

9 Food and Agricultural Organisation/World Health Organisation/United Nations University. Energy and protein require-

10 ments. Geneva: WHO, 1985. (Technical report series 724 .) caucasian children. 2: Nutrition, feeding practices and caucasian children. 2: Nutrition, feedir

11 Warrington S, Storey DM. Comparative studies of Asian and caucasian children. 1: Growth. Eur $\mathcal{f}$ Clin Nutr 1988;42: caucasian.

12 Harris RJ, Armstrong D, Ali R, Loynes A. Nutritional survey of Bangladeshi children aged under 5 years in the London borough of Tower Hamlets. Arch Dis Child 1983;58:428-32.

13 Jones VM. Current infant weaning practices within the Bangladeshi community in the London borough of Tower Hamlets. Human Nutrition: Applied Nutrition 1987;41A: 349-52.

14 Jivani SKM. The practice of infant feeding among Asian immigrants. Arch Dis Child 1978;53:69-73.

15 Hall DMB, eds. Health for all children. A programme for child health surveillance. The report of the joint working party on child health surveillance. Oxford: Oxford Medical Publications, 1989.

16 Picciano MF, Deering RH. The influence of feeding regimens on iron status during infancy. Am $\mathcal{F}$ Clin Nutr 1980;33: 746-53. 